\title{
An exploratory study of recent trends in the diversification of Dutch publishing companies in the multimedia and information industries
}

Citation for published version (APA):

van Kranenburg, H. L., Hagedoorn, J., \& Cloodt, M. M. A. H. (2001). An exploratory study of recent trends in the diversification of Dutch publishing companies in the multimedia and information industries. International Studies of Management \& Organization, 31, 64-86. https://doi.org/10.1080/00208825.2001.11656808

Document status and date:

Published: 01/01/2001

DOI:

10.1080/00208825.2001.11656808

Document Version:

Publisher's PDF, also known as Version of record

Please check the document version of this publication:

- A submitted manuscript is the version of the article upon submission and before peer-review. There can be important differences between the submitted version and the official published version of record. People interested in the research are advised to contact the author for the final version of the publication, or visit the DOI to the publisher's website.

- The final author version and the galley proof are versions of the publication after peer review.

- The final published version features the final layout of the paper including the volume, issue and page numbers.

Link to publication

\footnotetext{
General rights rights.

- You may freely distribute the URL identifying the publication in the public portal. please follow below link for the End User Agreement:

www.umlib.nl/taverne-license

Take down policy

If you believe that this document breaches copyright please contact us at:

repository@maastrichtuniversity.nl

providing details and we will investigate your claim.
}

Copyright and moral rights for the publications made accessible in the public portal are retained by the authors and/or other copyright owners and it is a condition of accessing publications that users recognise and abide by the legal requirements associated with these

- Users may download and print one copy of any publication from the public portal for the purpose of private study or research.

- You may not further distribute the material or use it for any profit-making activity or commercial gain

If the publication is distributed under the terms of Article $25 \mathrm{fa}$ of the Dutch Copyright Act, indicated by the "Taverne" license above, 
Int. Studies of Mgt. \& Org., vol. 31, no. 1, Spring 2001, pp. 64-86.

(C) 2001 M.E. Sharpe, Inc. All rights reserved.

ISSN $0020-8825 / 2001 \$ 9.50+0.00$.

Hans van Kranenburg, Myriam Cloodt, and

JOHN HAGEDOORN

\title{
An Exploratory Study of Recent Trends in the Diversification of Dutch Publishing Companies in the Multimedia and Information Industries
}

\begin{abstract}
In this exploratory study we investigate the investment strategies of companies in a traditional sector that faces important challenges from new technologies. We focus on the various forms of investment and divestment that are used by companies to achieve diversification. Using data from a small sample of leading Dutch publishing companies, we apply a multinomial logit analysis to model the investment preferences of these firms. Our data show that these leading companies in the industry diversify into new activities that are centered around the Internet, e-business, and other electronic products and services. These firms are found to prefer a gradual diversification through related activities. In terms of international diversification, the current strength of the new economy, expressed in major new technological developments and the creation of new businesses, affects the investment strategies of these companies through their strong preference for North American activities.
\end{abstract}

Hans van Kranenburg is assistant professor of strategy and econometrics at the University of Maastricht; Myriam Cloodt is a doctoral candidate at the University of Maastricht; and John Hagedoorn is professor of strategy at the University of Maastricht: Faculty of Economics and Business Administration, Department of Management Sciences, P.O. Box 616, 6200 MD Maastricht, the Netherlands (Tel: +31(0)43-388-3823; fax: +31(0)43-3884893; email: H.vanKranenburg@MW.Unimaas.nl; M.Cloodt@MW.Unimaas.nl; J.Hagedoorn@MW.Unimaas.nl).The authors gratefully acknowledge the research assistance of Laura Willemsen in collecting the data for this paper. 
In today's information market, the speed of growth is, according to many observers, the key to success in the new economy. Originally, the information market consisted of publishing and broadcasting companies, but the introduction of new information technologies, such as the Internet, forces traditional companies to reconsider their strategy and their product portfolio. Mergers, acquisitions, and joint ventures have become an integral part of strategic initiatives of many multimedia companies. To survive, companies have to capitalize on the trends of business globalization, industrial consolidation, and rapid integration of different communication segments by capturing a developed consumer base and accelerating the implementation of new technologies with combined resources. Multinational media conglomerates have expanded horizontally, vertically, and globally to maximize their competitive advantages and to strengthen their product portfolio. The existing companies are also moving away from their established traditional markets into product areas of the new economy.

In the traditional publishing industry, a few companies dominated the market due to their superior product technology and productivity. Mergers, acquisitions, and joint ventures allowed them to incorporate new innovations without running the risk that accompanies the initial development and introduction of these innovations. This article investigates the most recent trends in the diversification of Dutch publishing companies in the information and communications industry that is generally considered the core business of the new economy (Lichtenberg, 1999). Although Dutch publishing companies are among the world's leading firms in this industry, there are, to the best of our knowledge, no studies on these companies that examine their investment strategies in the light of the current changes in information and communications technology. However, it is known that multinational publishing companies such as Reed Elsevier, Wolters Kluwer, and VNU have expanded in all directions to maximize their growth potential. In the last three years, these three multimedia companies, established in the Netherlands, were involved in more than 100 mergers and acquisitions. Therefore, our exploratory study of these developments in the Dutch publishing industry can also be seen as a case study on the investment strategy of companies in a traditional sector that faces important challenges from new technologies.

Drawing from the existing literature, we develop four hypotheses regarding investment decisions, strategies, and location advantages to catch up with new technological developments and trends. We will particularly focus on the joint ventures, mergers, and acquisitions that companies engage in as they are redirecting their activities. The empirical testing of the hypotheses is based on investment events of the three Dutch multinational publishing companies for the period 19972000. More specifically, our analysis attempts to discover a pattern in the mergers, acquisitions, and joint ventures that publishing companies establish in order to capture the innovations of the information and communication industries.

We will first outline the small set of hypotheses to be tested. Although our study is largely exploratory with an emphasis on empirical findings, we will relate our 
hypotheses to the current body of knowledge on investment and divestment strategies; the role of mergers, acquisitions, and joint ventures; related and unrelated diversification; and international strategies. In order to provide some background to our statistical analysis, we will present a short outline of major industrial and technological developments in the Dutch publishing industry and present a short description of the three major companies that are analyzed in this article. This qualitative information is followed by sections in which we describe the data and the set of variables that is being used and give a short introduction to the statistical analysis by means of a multinomial logit model. We will separately discuss the results of our exploratory research and outline the main conclusions from this study. Given the nature of our contribution we will also present a number of recommendations for further study.

\section{Conceptual framework and hypotheses}

In the management literature, mergers and acquisitions are discussed as major mechanisms to improve the long-term performance of companies through increased innovative capabilities, additional R\&D efforts, and improved rates of product introduction (Chakrabarti, Hauschildt and Sueverkruep, 1994; Hitt, Hoskisson, Johnson, and Moesel, 1996; Oster, 1994). Empirical studies by Grandstrand, Bohlin, Oskarsson, and Sjoberg (1992) and Link (1988) demonstrate that, if mergers and acquisitions are properly managed, they can be an important element in the technology acquisition strategy of companies, particularly in innovative industries.

However, while using mergers and acquisitions to improve their performance, companies also need to evaluate and reconsider their existing businesses. Hence, the strategy of companies in a rapidly changing environment may encompass several actions such as divestment, joint venture, merger, and acquisition involving diversification - into either related or unrelated activities - and internationalization. ${ }^{1}$ The following sections discuss these broad consolidation options.

\section{Divestment}

For companies operating in industries subject to substantial change due to technological development, new entries, or changes in consumer preferences, some of the existing product-market offerings might no longer generate the normal and necessary returns on investment. In order to maintain a combination of rent-generating but high-risk new activities and less risky activities with normal returns through run-of-the-mill operations, companies will occasionally divest some of their existing businesses. In addition to this "balanced portfolio" line of argument, divestments are also undertaken to finance some of the new activities in which a company intends to engage. Based on the well-known BCG matrix and the product life-cycle understanding of business opportunities, there is a vast body of contributions to the management literature that suggests that companies should divest 
those activities that are characterized by a low attractiveness of their existing product-market combinations and a weak competitive position for the firm (see Besanko, Dranove, and Shankley, 1996, for a clear summary of this part of the management literature). In other words, we can expect that divestments will be found primarily in the already existing and established activities of companies and not so much in the new activities and new businesses in which companies are engaged. It is obvious that companies can, in case of failure, also divest some of their new activities, but, following the current management literature, we would expect that the majority of divestments would primarily be found in existing activities. These arguments lead to our first hypothesis:

\section{Hypothesis 1: Divestment activities of companies occur primarily in existing activities and not in new activities and businesses.}

\section{Acquisitions and joint ventures}

A number of seminal contributions to the literature on majority acquisitions, minority acquisitions, and joint ventures express that these different options are important elements in the strategy of companies to respond to uncertainty (Pfeffer, 1972; Sutton, 1980; Williamson, 1996). Companies particularly face uncertainty when it comes to adjusting to changes in their existing environment or to external changes that might create new competitive conditions. The absorption of at least parts of their environment (i.e., other companies) by means of acquisitions and joint ventures is one of the alternatives that companies have if they attempt to reduce uncertainty, increase control over environmental changes, or reduce their dependency on an existing environment (Hagedoorn, 1993; Harrigan, 1985; Hoskisson and Hitt, 1994; Mowery, 1988; Oster, 1994; Williamson, 1996). In the early 1970s, Pfeffer (1972) noted that the absorption of other companies or parts of other companies by means of acquisitions or joint ventures as a response to uncertainty can take place through either the integration of companies in the sector(s) in which a company is already operating or the diversification into another sector because the company has become too dependent on its existing environment. In the following section, we will take a slightly different perspective as we consider in particular the behavior of companies with regard to their choice of mixing existing activities with new businesses or a completely new set of activities. In other words, we consider whether companies diversify into related businesses (a combination of existing and new activities) or whether they diversify into businesses with which they have had little or no previous experience.

\section{Diversification into related and unrelated activities}

A substantial part of the current literature seems to suggest that in general the search for new activities through unrelated diversification by means of acquisi- 
tions has been less successful for most companies than the search for new activities through related acquisitions (Datta, 1991; Kusewitt, 1985; Oster, 1994; Porter, 1987; Singh and Montgomery, 1987). As shown by Datta (1991), there are also studies that find little or no evidence of such a relationship. Theoretically, however, the idea that companies should attempt to enter into new activities through the acquisition of related businesses remains appealing. Obviously, a company would be expected to profit from related acquisitions (both full and partial) by economies of scale and scope that should generate more synergetic benefits than in the case of unrelated acquisitions that have no relationship other than becoming part of one overarching system of corporate control.

Research on joint ventures and other forms of alliances generates somewhat similar insights. Beamish and Banks (1987), Beamish and Inkpen (1995), Geringer (1988), Geringer and Hebert (1989), Hagedoorn (1993 and 1995), Harrigan (1985), and Mowery (1988) found that joint ventures and alliances with complementary (i.e., related) partners were beneficial for most companies. This line of research suggests that complementarity is a major driver of partnering behavior. Therefore, a strategy aimed at creating joint ventures that are complementary to endogenous capabilities could have a more positive effect on company performance than the formation of joint ventures that either parallel existing capabilities or are unrelated to existing activities.

Therefore, the current understanding of both acquisitions and joint ventures suggests, among other things, that a rational strategy for companies would be to use both "vehicles" to diversify into related activities that are a mix of existing and new activities. This leads to the following related hypotheses:

\section{Hypothesis 2a: Companies prefer diversification into related activities that are a mixture of existing and new activities to diversification into unrelated activities.}

\section{Hypothesis 2b: Companies use both acquisitions and joint ventures to diversify into a mix of existing activities and new businesses.}

\section{International diversification}

Given the degree of international activities of most companies, both in sales and production, many are confronted with the choice for international or domestic diversification. This choice implies not only that companies have to decide whether they intend to acquire other businesses domestically or internationally, it also means that once a choice for international diversification is made, companies still have to consider a certain concentration on particular countries or international regions. These questions are not only relevant for acquisitions but also apply when companies consider international joint ventures.

Previous research on the internationalization of new and innovative activities through acquisitions and joint ventures suggests positive effects of international 
diversification on the performance of companies (Freeman and Hagedoorn, 1995; Hitt et al., 1997; and Hoskisson and Hitt, 1994). These positive effects are largely due to different local advantages generated by international sourcing through acquired companies and partner companies. Of particular importance in this context is the so-called agglomeration effect, which indicates that companies make use of the network externalities created by a large number of companies in a particular region or a country that has a particular advantage. Clear examples of this phenomenon are found in the electronics and pharmaceutical industries in particular regions of the United States where local companies have created such a comparative advantage that non-U.S. companies enter into new activities and new businesses through acquisitions and joint ventures with U.S. companies. This leads us to our next hypothesis.

\section{Hypothesis 3: International investment strategies of companies concentrate on new activities in a particular region or a country that has a relevant comparative advantage.}

\section{The publishing industry in the Netherlands}

The Netherlands has a long and distinguished publishing tradition. Building on this tradition while benefiting from the continuing worldwide dependence on information needs, Dutch publishers have become prominent global information providers. According to WorldScope, the three largest publishing companies from the Netherlands that we analyze in this article are among the leading publishers in Europe. Table 1 shows a ranking of the top ten European publishing companies. Moreover, the publishing industry in the Netherlands contributes about 23 percent of total net sales of European publishing companies. Furthermore, Dutch companies are still improving their international position. During recent years, they have become major acquirers of other businesses and companies. For instance, in 1999 Dutch publishers contributed to about 45 percent of the total amount spent on acquisitions by European publishing companies (calculated from WorldScope, 2000).

Several characteristics of the Dutch publishing industry have contributed to the prominent role that these companies play in the extended multimedia landscape. First, after World War II a number of technological inventions such as electronic printing and communication systems changed the structure of the Dutch publishing industry dramatically. Economies of scale and scope forced Dutch companies into a merger movement and closer cooperation within the industry in order to survive in increasing competition (de Ridder, 1984). During the 1960s and 1970s nearly all large mergers in the Dutch publishing industry were horizontal mergers. The first was the merger of De Spaarnestad and Teulingsconcern in 1964, which became VNU. During that period the merger wave in the publishing industry was mainly based on the need to create a stronger competitive position and develop a 


\section{Table 1}

Top ten publishing companies in Europe, 1999

\begin{tabular}{lll} 
Rank & Company Name & Country \\
\hline 1 & Bertelsmann AG & Germany \\
2 & Reed Elsevier & the Netherlands/United Kingdom \\
3 & Pearson PLC & United Kingdom \\
4 & United News \& Media PLC & United Kingdom \\
5 & Wolters Kluwer NV & the Netherlands \\
6 & Axel Springer Verlag AG & Germany \\
7 & VNU NV & the Netherlands \\
8 & Daily Mail \& General Trust PLC & United Kingdom \\
9 & Hachette Filipacchi Medias SA & France \\
10 & EMAP PLC & United Kingdom
\end{tabular}

Source: WorldScope (2000)

strategic position in a new submarket. However, all operations were still focused on the Dutch domestic market (Van den Brink, 1987).

Since the end of the 1970s, the strategy of many Dutch publishing companies has changed toward a focus on growth in foreign markets. A very important element of the international diversification strategy is found in the preference for the location of acquired companies in specific regions. Dutch publishers are becoming more focused on acquiring specialized media companies in North America, mainly through the acquisition of state-of-the-art electronic publishing or multimedia companies (Bennett, 1999; Van den Brink, 1987). It is well known that North America, particularly the United States, is the region where most of the new electronic publishing technologies and new media are developed (Lichtenberg, 1999).

The use of new information and communication technologies are a new phase in the evolution of the publishing industry. Publishing companies are entering new product life cycles (Vernon, 1966; Klepper, 1997), for instance through Internet businesses that have been operating for less than a few years. It is expected that the critical mass for the general acceptance of these new activities will be probably reached within a decade (Lichtenberg, 1999). New technologies such as the Internet, online subscription services, and e-books make it possible to combine old and new media into one product with an additional element that was missing in the earlier markets: interactivity. Therefore, publishing is now part of the global information and communication industries and interacts with many different fields within this group of industries and technologies. Because of this diversification, publishing companies have to redefine their "core business." However, to use these technologies in a competitive way, substantial investment in capital and expertise is required. Often the current technology base of publishing companies is limited. For 


\section{Table 2}

\section{Definition of the investment modes of diversification}

Industries

Examples of products

\begin{tabular}{|c|c|}
\hline \multicolumn{2}{|c|}{ Traditional diversification } \\
\hline hard-copy publishing activities & books, newspapers, journals, magazines \\
\hline professional services & shows, conferences, and fairs \\
\hline entertainment & radio, television, and movies \\
\hline \multicolumn{2}{|c|}{ Unrelated diversification } \\
\hline $\begin{array}{l}\text { electronic services } \\
\text { and electronic products }\end{array}$ & $\begin{array}{l}\text { online information services, e- } \\
\text { commerce, software systems, } \\
\text { databases, CD-ROMs, websites, } \\
\text { internet providers }\end{array}$ \\
\hline \multicolumn{2}{|c|}{ Related diversification } \\
\hline $\begin{array}{l}\text { combination of traditional publishing } \\
\text { activities and electronic services } \\
\text { and products }\end{array}$ & $\begin{array}{l}\text { journals, online information services, } \\
\text { books, CD-ROMs, newspapers } \\
\text { and yellow pages }\end{array}$ \\
\hline $\begin{array}{l}\text { combination of professional services } \\
\text { and electronic services and products }\end{array}$ & $\begin{array}{l}\text { conferences and online information } \\
\text { services, shows and websites }\end{array}$ \\
\hline $\begin{array}{l}\text { combination of entertainment and } \\
\text { electronic services and products } \\
\text { marketing and information services }\end{array}$ & $\begin{array}{l}\text { movies and DVDs } \\
\text { (online) business-to-business marketing } \\
\text { research and consulting services }\end{array}$ \\
\hline
\end{tabular}

companies lacking new competencies, several options are open to acquire the essential technological knowledge. Mergers, acquisitions, and joint ventures with companies that are active in the information and communications technology-based new economy are an important option to gain new competencies. Examples of these competencies are found in a wide variety of new activities and new interactive products such as electronic services and electronic products, new professional services, electronic entertainment, and business-to-business marketing and information services (see Table 2 for a more detailed overview of these products). ${ }^{2}$

To provide some insight into the specific strategic reactions of Dutch publishing companies to the recent technological developments in the publishing industry, we selected the three leading publishing companies in the Netherlands: Reed Elsevier, Wolters Kluwer, and VNU (number one, two, and three, respectively). Table 3 shows the key financial information for these leading publishing companies. With respect to acquisitions, VNU shows the most aggressive diversification strategy. It spent a total net amount of $€ 4.712$ billion on acquisitions within three years. Reed Elsevier and Wolters Kluwer spent a total net amount of $€ 2.05$ billion and $€ 1.897$ billion on acquisitions, respectively. 


\section{Table 3}

Key financial information of the top three publishing firms in the Netherlands (in million euros) ${ }^{\mathrm{a}}$

\begin{tabular}{|c|c|c|c|c|c|c|}
\hline & \multicolumn{2}{|c|}{ Reed Elsevier } & \multicolumn{2}{|c|}{ VNU } & \multicolumn{2}{|c|}{ Wolters Kluwer } \\
\hline & $\begin{array}{c}\text { Net } \\
\text { revenue }\end{array}$ & $\begin{array}{l}\text { Balance of } \\
\text { acquisitions } \\
\text { minus } \\
\text { divestments }\end{array}$ & $\begin{array}{c}\text { Net } \\
\text { revenue }\end{array}$ & $\begin{array}{l}\text { Balance of } \\
\text { acquisitions } \\
\text { minus } \\
\text { divestments }\end{array}$ & $\begin{array}{c}\text { Net } \\
\text { revenue }\end{array}$ & $\begin{array}{l}\text { Balance of } \\
\text { acquisitions } \\
\text { minus } \\
\text { divestments }\end{array}$ \\
\hline 1997 & 4324 & 1002 & 1779 & 320 & 2364 & 425 \\
\hline 1998 & 4708 & 538 & 2427 & 2080 & 2739 & 1058 \\
\hline 1999 & 5153 & 510 & 2809 & 2312 & 3081 & 414 \\
\hline \multicolumn{7}{|c|}{ 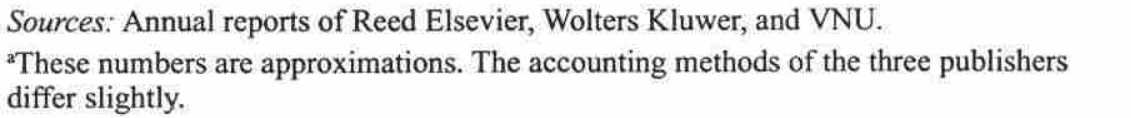 } \\
\hline
\end{tabular}

In the following sections, we will briefly discuss the different strategies followed by Reed Elsevier, Wolters Kluwer, and VNU in dealing with fuller development of new activities and new businesses that come with the new information and communication technologies. ${ }^{3}$ These short descriptions provide a background against which we can interpret the findings of the statistical analysis presented in subsequent sections.

\section{Reed Elsevier}

Elsevier, founded in 1880, merged with Reed in 1992, after which the company came to be known as Reed Elsevier. Through the merger, it became strongly represented in North America, Europe, and the Asia Pacific region. Reed Elsevier is a leading publisher and information provider globally, with a focus on three key market areas: science, law, and business. Its businesses in the scientific division publish more than 1,200 journals worldwide in the physical, life, social, and medical sciences, and the company operates an international network of medical communications services. Reed Elsevier's law division serves, through a variety of publishing formats, important legal, tax, reference, and educational markets around the world. The activities within the business division comprise leading business magazine and information companies and a worldwide exhibitions business. Each of these markets is large and grows at 4-7 percent annually. Its two parent companiesReed International P.L.C. and Elsevier NV - are listed on the Amsterdam, London, and New York Stock Exchanges. Reed Elsevier employs over 26,000 people.

Reed Elsevier's product-markets are undergoing rapid and accelerating changes. This means that Reed Elsevier will be confronted with the migration of informa- 
tion from print to electronic format and the additional interactivity that electronic services offer. Based on this change, the principal objective for Reed Elsevier is to be an indispensable partner to their target consumers for information-driven services that provide solutions across their three core areas of focus. Capitalizing on the potential of the Internet seems to be a key driver of Reed Elsevier's strategy. Acquisitions and alliances, particularly in the context of Internet development, are used to reinforce Reed Elsevier's strategy. At this moment, the three core businesses are all transitioning into electronic markets. All of them are becoming more global, and the Internet is rapidly becoming the preferred customer access system for all three.

Reed Elsevier has already introduced numerous innovative services and products. Examples include the launch of ScienceDirect, the fully searchable online database comprising content from over 1,000 of their scientific journals. In legal publishing, Butterworths, a Reed Elsevier subdivision, launched Butterworths Direct, the most comprehensive online legal service for English law. Furthermore, LEXIS-NEXIS, another subdivision of Reed Elsevier, introduced its universal current awareness web browser product for the business market.

However, it appears that to some degree Reed Elsevier has underinvested in new product development, marketing, and sales. This is a key factor behind the lack of growth in both particular traditional markets and new Internet businesses. Reed Elsevier therefore budgeted $€ 420$ million for new development initiatives in 2000 compared to an average $€ 80-120$ million in previous years. This level of investment will be followed by a three-year investment package totaling in excess of $€ 1.2$ billion. Around 90 percent of these investments will be Internet related, including new product and technology development, marketing, and sales. Reed Elsevier expects that in the year 2002 a quarter of its revenue, $€ 1.5$ million, will come from the Internet.

To change Reed Elsevier from a traditional "paper" company into an electronic publisher that can survive in a rapidly changing industry demands a huge reorganization. The Internet activities of the company will be organized separately and have distinct management responsibilities and accountability. Although the electronic media group will work closely with the printing brands and marketing, they will also independently pursue growth opportunities in existing and carefully defined new market segments. In addition, the company established a venture fund of initially up to $€ 100$ million to make early stage investments in Internet-related businesses, to provide insight and involvement in these new markets and new technology initiatives, and to generate adequate financial returns.

\section{Wolters Kluwer}

Wolters Kluwer is a provider of information and workflow tools for professionals throughout Europe, North America, and the Asia Pacific region. It is listed on the Amsterdam stock exchange. The company describes its strategic objectives in terms of providing comprehensive, authoritative, and reliable print and electronic infor- 
mation products and services to help professionals reduce costs and increase productivity, efficiency, and effectiveness. Wolters Kluwer, which employs almost 18,000 people, focuses on three different markets: legal, tax, and business; international health and science; and educational publishing.

An increasing number of Wolters Kluwer's customers are using the Internet, which implies that in recent years the company had to make very significant effort and investment to respond to the shift from a print to an electronic format. Electronic publishing revenues in 1999 were over $€ 550$ million. The company has extended these efforts by investing an additional $€ 250$ million to accelerate migration to the Internet, to build new products, and to attract new customers over the course of 2000-2002.

Furthermore, the company will realign its businesses into five operational clusters to focus attention on specific customer groups and execute its Internet strategies. Each of these five operational clusters (legal, tax, and business, Asia Pacific; legal, tax and business, North America; legal, tax and business, Europe; international health and science; and educational publishing) has important Internet challenges and opportunities. This requires the creation of individual cluster-specific online businesses that are expected to provide quick access to all existing content, services, and software products on the company's Internet platform. Recently, Wolters Kluwer established a Corporate Technology Organization headed by a chief technology officer. The role of this technology organization is to assist the cluster organizations in implementing their Internet strategies. Standardized platforms in North America and Europe will provide the essential hardware and software infrastructure and development services necessary to host and support the Internet activities of the five clusters. By establishing this organizational structure, Wolters Kluwer is attempting to combine the advantages of a decentralized Internet strategy with better coordination of their investments across their businesses.

\section{$V N U$}

VNU is active in the markets for both consumer and professional information services. More specifically, its core activities are consumer magazines, telephone directories, and information services; business information; and educational publishing. Its objective is to grow further in professional publishing and to expand its businesses in the United States. Currently, approximately half of its revenues come from professional publishing and about 40 percent of its revenues are generated in the United States. VNU, which employs about 16,000 people, is active in eighteen European countries, the United States, Canada, Puerto Rico, India, and South Africa. It is listed on the Amsterdam, Brussels, and Luxembourg stock exchanges.

VNU's strategy is directed toward growth and further expansion in key areas like marketing, information services, new clusters of business information in the United States and Europe, consumer magazines, directories, and other information services. In 1999, VNU made an important move in fulfilling its intentions by 
acquiring Nielsen Media Research, the market leader in Internet audience monitoring in the United States. Furthermore, VNU recognizes that although paper is still an important source of information, electronic information services are already heavily used in the world of professional information processing. In consumer information markets, the penetration of new media is expected to have a more gradual character. VNU's strategic intention is to play a leading role in the expansion of new electronic product offerings, and for that reason it is heavily investing in new technologies. Development costs relating to its Internet operations were approximately 30 million euros in 1999. In that same year, approximately 200 employees were involved in Internet operations. In the United States, VNU already operates websites that are profitable (for example Billboard online and Adweek online). This is rather unique, since normally Internet activities still demand large investments but generate very little income. With the acquisition of World Directories, VNU has strengthened its long-term position to become an active player in the new interactive media. VNU has streamlined the organization of some of its Internet operations in Europe by forming a central Internet business unit, VNU Internet Publishing. This business unit sets up new Internet projects involving several divisions and provides support for existing Internet activities within VNU.

It is clear from the above descriptions that considerable overlap exists in the market segments in which these three publishing companies are operating. For example, Wolters Kluwer and Reed Elsevier both focus on the legal and science areas, and VNU and Wolters Kluwer are involved in educational publishing. However, from an organizational viewpoint these publishers differ substantially. VNU centralizes some of its Internet operations in Europe, as a result of which an Internet project can involve several core activities. Wolters Kluwer, on the other hand, has chosen for a decentralized approach whereby each core activity can develop its own specific Internet strategy. The activities of Reed Elsevier are organized separately from the printing and marketing activities, leading to a more functional division. However, all three publishing companies substantially increased their investments in new electronic and online businesses, emphasizing that they are actively involved in becoming major players in the relevant markets of the new economy.

\section{Data and variables used in the statistical analysis}

In order to test the hypotheses that we developed above, we constructed a data set on the investment activities of these three Dutch multinational publishing companies. As mentioned, we selected these publishing companies because they are companies that are global leaders, operating mainly in Europe and North America. The period under investigation starts in January 1997 and ends in April 2000. The data set is mainly compiled from information published by Reed Elsevier, VNU, and Wolters Kluwer and some additional sources. For this additional information we consulted Dunn and Bradstreet data, Reach, WorldScope, newspapers, and specialized journals which report on business events. Despite the high quality of the 
Table 4

Consolidation strategies for each publishing company, 1997-2000

\begin{tabular}{|c|c|c|c|c|c|c|}
\hline & Mergers & $\begin{array}{c}\text { Majority } \\
\text { stake }\end{array}$ & $\begin{array}{c}\text { Minority } \\
\text { stake }\end{array}$ & $\begin{array}{c}\text { Joint } \\
\text { ventures }\end{array}$ & Divestments & Total \\
\hline Reed Elsevier & 1 & 40 & 3 & 5 & 12 & $61(35 \%)$ \\
\hline VNU & 3 & 41 & 7 & 11 & 10 & $72(41 \%)$ \\
\hline WoltersKluwer & - & 34 & 2 & - & 6 & $42(24 \%)$ \\
\hline Total & 4 & 115 & 12 & 16 & 28 & 175 \\
\hline
\end{tabular}

available data, the nature of the effort most likely (and unavoidably) resulted in some inaccuracies. These probably involve the omission of some small acquisitions and minor divestments. In total we monitored 175 investment events for the publishing companies from 1997 to 2000. Table 4 shows that Reed Elsevier was involved in 61 (or 35 percent) of the total number of investment events, VNU in 72 (or 41 percent), and Wolters Kluwer in 42 (or 24 percent) of the investment events. We were also able to obtain some information about the nature of these investment activities. The most common investment strategy for these publishing companies is to make a majority-stake acquisition. In 115 cases, a share of more than 50 percent in another company was acquired, although in only 12 cases did these companies acquire a minority stake. Twenty-eight cases refer to the divestment of a business unit. There were 16 cases in which these publishers entered into joint ventures with other companies in the information and entertainment businesses. Only in four cases did a subsidiary of a publisher merge with another venture. It should be noted that one publisher apparently did not apply all investment strategies. Wolters Kluwer did not use a merger or joint venture to consolidate during the period of our investigation.

Table 5 shows the geographical distribution of investment activities of the sample firms. Although the distribution is not uniform among the companies, the majority of investment activities of the publishers have taken place in North America (United States and Canada) and Western Europe (the European Union and the European Free Trade Association [EFTA]). The investment strategy of Reed Elsevier is mainly focused on North America, since 69 percent of its consolidation activities were located in that part of the world. Wolters Kluwer and VNU invested more in Euope (including Eastern Europe): 56 percent and 68 percent, respectively.

In order to test the hypotheses on company investment strategies related to existing and new activities, the unit of analysis is the investment choice. However, we also investigate the differences in strategy between the publishing companies, especially the differences in their individual location decisions and the form of consolidation. The relevant unit of analysis for testing these firm-specific characteristics is the firm itself. We aggregated all kinds of acquisitions by the companies to one variable. We defined a merger as an acquisition because subsidiaries of the 


\section{Table 5}

Distribution of publishing company investment activities, 1997-2000 (percent)

Africa Australia Asia $\begin{gathered}\text { Eastern } \\ \text { Europe }\end{gathered}{\text { EFTA } A^{\text {a }}}^{\text {America }}$ America

$\begin{array}{llllllll}\text { Reed Elsevier } & 0 & 2 & 0 & 0 & 26 & 3 & 69 \\ \text { VNU } & 1 & 0 & 1 & 9 & 59 & 0 & 30 \\ \text { Wolters Kluwer } & 0 & 0 & 0 & 0 & 56 & 0 & 44\end{array}$

"European Free Trade Association.

publishing companies merged but not their parent companies. The merged subsidiary is still owned by the publisher.

\section{Definitions of the variables}

The dependent variable in the first part of the following statistical analysis is the investment mode. The investment mode is categorized as traditional diversification (a company only diversifies into existing activities and businesses), unrelated diversification (diversification into new activities and businesses with which the company had little or no previous experience), or related diversification (the company diversifies into a mix of existing activities and new businesses).$^{4}$

The operationalization of the explanatory variables is briefly described in Table 6. Straightforward single-item measures were used for the variables.

Table 7 provides descriptive statistics and correlation coefficients for all variables. $\mathrm{N}$ is the number of observations and s.d. is the standard deviation. Further analysis of these data demonstrates that multicollinearity is not a major concern for our study.

\section{Methods and specification of analysis}

Statistical models of discrete choice can be applied when, as is the case in our contribution, the dependent variable represents discrete events. In the context of this paper there are three states in which an investment choice can be categorized as: (1) diversification into only (traditional) existing activities and businesses, (2) diversification into unrelated new activities and businesses, or (3) diversification into a combination of existing and new activities and businesses. The simplest models of this type involve only a set of three alternatives in no particular order represented by a ternary, $0-1-2$, dependent variable $Y_{i}$. Therefore, our analysis begins with a three-state discrete choice model because in this situation companies choose among three investment options based on the product categories that specify either existing activities, new activities, or a mixed investment. A multinomial logit model is employed in order to relate the investment intentions of com- 


\section{Table 6}

Measurement of Independent variables

Variable

Measure

\section{Investment strategy}

Divestment

Acquisition

Joint Venture

North America

Variable indicating if the action was a divestment.

Variable indicating if the investment was an acquisition.

Variable indicating if the entry in a business was a joint venture. Indicator of whether the investment activity was located in the United States or Canada.

\section{Firm-specific variables}

Company

Variable indicating if publishing company is Reed Elsevier, VNU, or Wolters Kluwer that invested.

\section{Control variables}

Year

Variable indicating if the investment took place in year $i$ of the investigation period. The four years are 1997, 1998, 1999, and 2000.

panies (as measured by one of the three investment modes) to strategic objectives and time effects. The multinomial logit model has been developed from a theory of probabilistic choices in economics (see, e.g., Maddala, 1983; Schmidt and Strauss, 1975). It is a widely used analytic method to test the significance of independent variables leading to investment choices.

Let the variable $Y_{i j}=j$, if the $i$ th observation chooses alternative $j, j=0,1,2$. In the current context $i$ represents investments in an activity or business and $j$ represents the kind of diversification where $Y_{i j}=0$ denotes traditional diversification, $Y_{i j}=1$ indicates unrelated diversification, and $Y_{i j}=2$ represents related diversification. The multinomial logit model for the probability that $Y_{i j}=\mathrm{j}, \mathrm{P}\left(Y_{i j}=\mathrm{j}\right), \mathrm{j}=0,1,2$ can be formulated as:

$$
\mathrm{P}\left(Y_{i j}=\mathrm{j}\right)=\exp \left(\alpha_{j}+\beta_{j} X_{i}\right) /\left[\sum_{j=0}^{2} \exp \left(\alpha_{j}+\beta_{j} X_{i}\right)\right],
$$

where $X_{i}$ represents the vector of characteristics of $i$ th observation.

The usual benchmark for comparison is the traditional diversification (state zero) and therefore we set $\alpha_{0}=\beta_{0}=0$ (Theil, 1969). This normalization permits us to calculate the probability of diversification investment in existing businesses, new businesses, and a combination of existing and new businesses as:

$$
\begin{aligned}
& \mathrm{P}\left(Y_{i j}=0\right)=1 /\left[1+\exp \left(\alpha_{1}+\beta_{1} X_{i}\right)+\exp \left(\alpha_{2}+\beta_{2} X_{i}\right)\right] \\
& \mathrm{P}\left(Y_{i j}=1\right)=\exp \left(\alpha_{1}+\beta_{1} X_{i}\right) /\left[1+\exp \left(\alpha_{1}+\beta_{1} X_{i}\right)+\exp \left(\alpha_{2}+\beta_{2} X_{i}\right)\right] \\
& \mathrm{P}\left(Y_{i j}=2\right)=\exp \left(\alpha_{2}+\beta_{2} X_{i}\right) /\left[1+\exp \left(\alpha_{1}+\beta_{1} X_{i}\right)+\exp \left(\alpha_{2}+\beta_{2} X_{i}\right)\right] .
\end{aligned}
$$




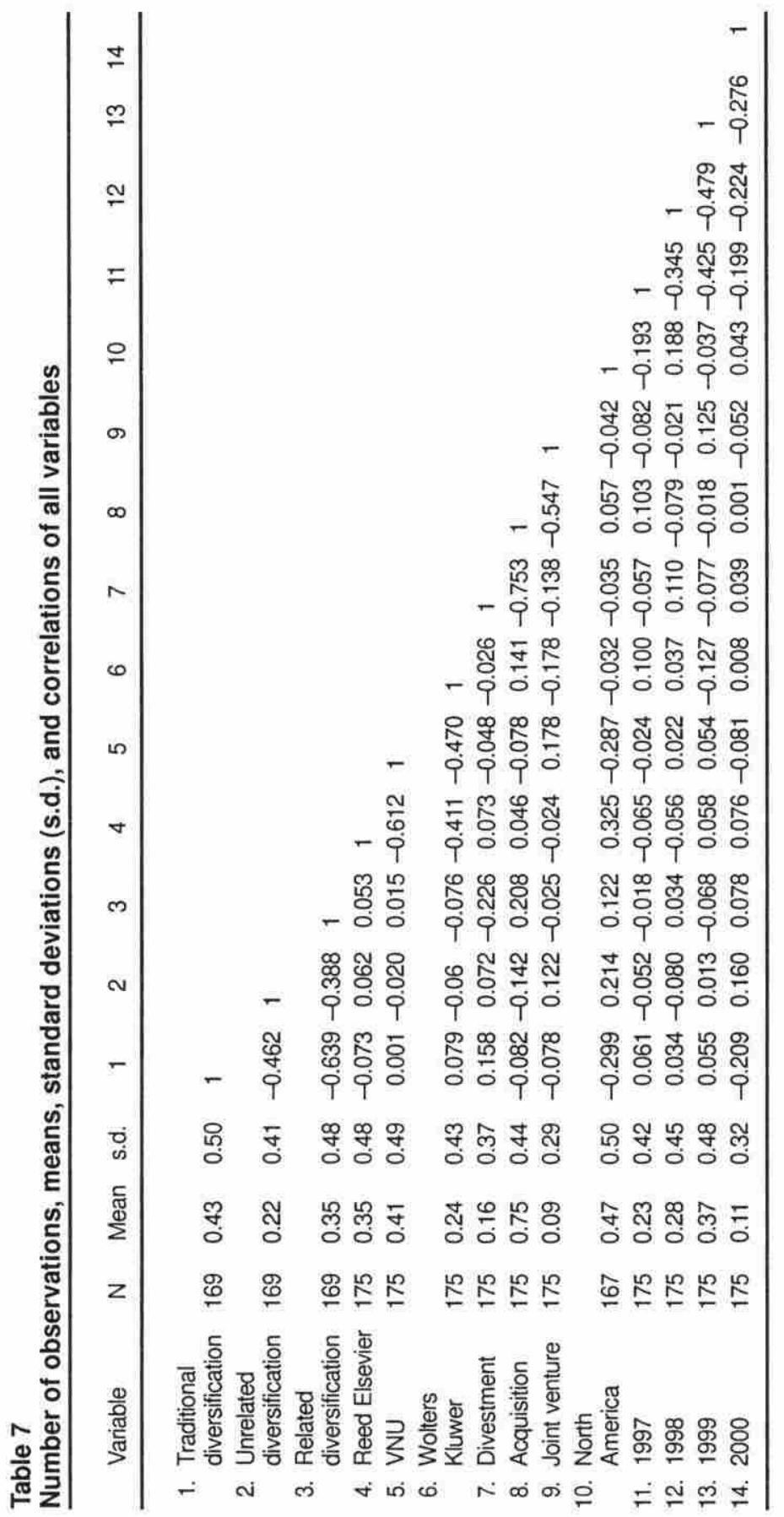


The parameters of the three-state multinomial logit model are estimated by maximizing the likelihood function. We used the statistical software programs LIMDEP 7.0 and SAS to compute the maximum likelihood estimates of the model.

A chi-square test is used to analyze the categorical data that refer to the possible differences between the three publishers. This chi-square test is the most appropriate method because we have nominal (frequency) data, where subjects are assigned to categories. The test is concerned with answering the question: Does a relationship exist between the variables of interest? This method compares the observed frequencies with the expected frequencies if there are no statistical relationships between the relevant variables.

\section{Results}

Parameter estimates of the multinomial logit model for the independent variables with acquisitions and joint ventures (and divestment as benchmarks) are presented in Table 8. Estimates for only two investment choices, unrelated diversification or related diversification, are provided because the normalization $\alpha_{0}=\beta_{0}=0$ implies that the coefficients for the investment choice of diversification into only (traditional) existing activities and existing businesses are all zero. Since the model for unrelated and related diversification investment estimates the coefficients of covariates, while constraining the coefficients of the existing diversification option to zero, we have to interpret coefficients as the marginal impact that these variables have on the probability of diversification investment in unrelated new or a combination of existing and new activities and businesses. We separately estimated the regressions by changing the strategy variables in order to observe the importance of these variables related to the prediction of the investment choices. The models are significant. The chi-square tests, $\chi^{2}(\mathrm{df})$, for covariates are significant at p-value of 0.01 . In terms of the overall fit of the models, the multinomial logit models correctly predict about 53 percent of events of diversification investment into only traditional, unrelated, and related activities and businesses.

Our first hypothesis suggested that firms would be more likely to divest their existing activities than their new activities and new businesses. In our benchmark acquisition and joint ventures model, the divestment estimate is insignificantly associated with the unrelated diversification, but there is a significant effect for related diversification. These results indicate that divestment by firms is less likely to occur in a combination of existing and new activities and businesses than in the traditional activities or in unrelated new activities.

Hypothesis 2a explores whether companies prefer to diversify into related activities that are a mixture of existing and new activities. In addition, we also hypothesized (2b) that firms use both acquisitions and joint ventures to diversify into a mix of new businesses and existing activities. The estimation results in the benchmark divestment model show that both consolidation strategies positively affect the likelihood of investment in related activities. The coefficient associated with joint ventures in the 
Table 8

Results for the three-stage multinomial logit model for investment options

\begin{tabular}{|c|c|c|c|c|}
\hline \multirow[b]{2}{*}{ Variable } & \multicolumn{2}{|c|}{$\begin{array}{l}\text { Benchmark acquisition } \\
\text { and joint ventures }\end{array}$} & \multicolumn{2}{|c|}{ Benchmark divestment } \\
\hline & $\begin{array}{c}\text { Unrelated } \\
\text { diversification }\end{array}$ & $\begin{array}{c}\text { Related } \\
\text { diversification }\end{array}$ & $\begin{array}{c}\text { Unrelated } \\
\text { diversification }\end{array}$ & $\begin{array}{l}\text { Related } \\
\text { diversification }\end{array}$ \\
\hline Constant & $\begin{array}{r}-1.7303^{\mathrm{a}} \\
(0.6066)\end{array}$ & $\begin{array}{r}-1.1607^{\circ} \\
(0.5319)\end{array}$ & $\begin{array}{r}-1.7814^{b} \\
(0.7722)\end{array}$ & $\begin{array}{l}-3.0163^{a} \\
(0.8580)\end{array}$ \\
\hline Divestment & $\begin{array}{l}-0.1215 \\
(0.5566)\end{array}$ & $\begin{array}{r}-1.8891^{a} \\
(0.6859)\end{array}$ & & \\
\hline Acquisition & & & $\begin{array}{c}-0.0815 \\
(0.5708)\end{array}$ & $\begin{array}{r}1.8547^{\mathrm{a}} \\
(0.6889)\end{array}$ \\
\hline Joint venture & & & $\begin{array}{c}1.4426 \\
(0.8779)\end{array}$ & $\begin{array}{l}2.1750^{\mathrm{b}} \\
(0.9610)\end{array}$ \\
\hline North America & $\begin{array}{l}1.9339^{\mathrm{a}} \\
0.5172\end{array}$ & $\begin{array}{r}1.1555^{\mathrm{a}} \\
(0.4361)\end{array}$ & $\begin{array}{r}2.0051^{\mathrm{a}} \\
(0.5276)\end{array}$ & $\begin{array}{r}1.1622^{\mathrm{a}} \\
(0.4383)\end{array}$ \\
\hline Reed Elsevier & $\begin{array}{c}-0.0560 \\
(0.5982)\end{array}$ & $\begin{array}{c}0.5115 \\
(0.5292)\end{array}$ & $\begin{array}{l}-0.2018 \\
(0.6051)\end{array}$ & $\begin{array}{c}0.4756 \\
(0.5315)\end{array}$ \\
\hline VNU & $\begin{array}{c}0.4234 \\
(0.5705)\end{array}$ & $\begin{array}{l}0.5887 \\
(0.5002)\end{array}$ & $\begin{array}{c}0.1278 \\
(0.5990)\end{array}$ & $\begin{array}{c}0.5602 \\
(0.5088)\end{array}$ \\
\hline 1997 & $\begin{array}{c}0.1005 \\
(0.5996)\end{array}$ & $\begin{array}{c}0.4215 \\
(0.5145)\end{array}$ & $\begin{array}{c}0.2320 \\
(0.6106)\end{array}$ & $\begin{array}{c}0.4127 \\
(0.5151)\end{array}$ \\
\hline 1998 & $\begin{array}{c}-0.6805 \\
(0.5731)\end{array}$ & $\begin{array}{c}0.2011 \\
(0.4851)\end{array}$ & $\begin{array}{l}-0.6427 \\
(0.5824)\end{array}$ & $\begin{array}{c}0.1884 \\
(0.4863)\end{array}$ \\
\hline 2000 & $\begin{array}{r}1.8368^{b} \\
(0.8050)\end{array}$ & $\begin{array}{r}1.6862^{b} \\
(0.8030)\end{array}$ & $\begin{array}{r}1.9497^{\circ} \\
(0.8129)\end{array}$ & $\begin{array}{r}1.6784^{b} \\
(0.8030)\end{array}$ \\
\hline $\mathrm{N}$ & \multicolumn{2}{|c|}{163} & \multicolumn{2}{|c|}{163} \\
\hline Log likelihood & \multicolumn{2}{|c|}{-174.0700} & \multicolumn{2}{|c|}{-174.0700} \\
\hline$\chi^{2}(\mathrm{df})$ & \multicolumn{2}{|c|}{$39.63^{\mathrm{a}}$} & \multicolumn{2}{|c|}{$43.84^{a}$} \\
\hline
\end{tabular}

Notes: Figures in parentheses are standard errors.

a significant at $\mathrm{p}<0.01$

${ }^{\mathrm{b}}$ significant at $\mathrm{p}<0.05$

benchmark divestment model, however, is greater than the one associated with acquisitions. This suggests that the probability of related diversification investment is higher for a joint venture than for an acquisition, but the difference is not statistically significant.

Table 8 also shows the results for hypothesis 3 . As predicted, the region estimates show that these publishing companies favor North America to other regions. This result reflects the fact that local companies in North America have created such a comparative advantage in the new information and communication businesses that European companies are forced to internationalize through North American investments to survive in this rapidly changing world.

Our results for the differences in firm-specific characteristics do not discrimi- 
nate between these companies and their preferences for certain investment modes. A direct interpretation of our findings is that all three companies have changed their traditional strategy and product portfolio. Apparently, these firms have the same investment strategy related to existing and new activities and businesses. However, some possible differences between firms may need some further discussion. As mentioned, Table 4 presents the frequencies for each publishing company with regard to the kind of strategy they followed. The calculated Pearson chisquare is 6.381 and the associated degree of freedom is $4 .^{5}$ This also indicates that there exists no relationship between the three companies and the strategies they have used. It demonstrates that all three publishers have followed more or less the same mix of diversification strategies.

Another interesting finding is the link between location and the firm's investment decision. The calculated Pearson chi-square test for Table 5 is 22.546 , and it is statistically significant. ${ }^{6}$ This result indicates that there exists a relationship between the three publishing companies and the location in which they are investing. Investments of Reed Elsevier and VNU differ substantially between North America and Europe, while investments of Wolters Kluwer are almost equally divided between the two regions.

With respect to the control variables in the multinomial logit analysis, the overall impression is that firms are becoming more focused on the acquisition of new activities. The year 2000 is positive and significant in all our models, while the other years are not significant in comparison to 1999. The coefficient associated with 1998 in the unrelated diversification equation is, however, negative. This shows that these firms have recently reconsidered their investment strategy in favor of new electronic and e-business activities.

\section{Conclusions}

We have applied both a qualitative approach, with a case study analysis of investment strategies of companies, and a quantitative approach, with a statistical analysis of the different characteristics of the investment preferences of companies. Not only do these different analyses indicate similar developments in the three leading Dutch publishing companies, both approaches also complement each other in terms of the specific information that is generated. In that sense this study provides a rather comprehensive picture of recent developments in the industry and its main players from the Netherlands.

What we have learned is that these leading companies do indeed diversify into a number of new activities that are centered around the Internet, e-business, and other electronic products and services - activities that form the core of the new economy. However, we also notice that these companies follow a strategy of gradual and related diversification into these new activities. In that sense their strategy can be seen as rational in that they appear to largely avoid "risky" diversification into unknown, new businesses that are completely unrelated to their current portfolio. 
This diversification into new multimedia and communications and information technology gains importance for our understanding of how these companies are changing if we realize that they almost simultaneously divested a number of their existing businesses in the traditional publishing sector. Both the divestment of some traditional activities and the investment in new but related businesses indicate that these companies are going through a rather rapid transition from traditional, single-industry publishing companies to companies that are operating in their traditional industry as well as in important new and developing activities that are related to the Internet and a wide range of multimedia services.

As expected, the current dominance of North America in these new businesses in terms of new markets and the supply of new companies and new technologies has a major impact on the investment strategies of these companies. Although there are some differences among them, a substantial share of their current product-market diversification into new activities is paralleled by a preference for new investments made outside Europe, in particular in the United States.

This study demonstrates that leading companies in a traditional sector such as the publishing industry prefer to diversify gradually through related activities. This finding supports those theories on diversification that stress the importance of a gradual change through related diversification that reduces the complexity for companies. Consequently, this also suggests that these companies follow the advice of those who warn of the dangers of unrelated diversification that creates complex problems for companies that enter into "unexplored territory."

However, from the perspective of the actual management of innovation processes within these companies, the emerging international distribution of new activities generates additional complexity. Because the momentum of the new economy - through new technological developments and new businesses - largely lays in the United States, companies outside North America have no alternative but to invest outside their home regions. This indicates that European companies have to place part of their innovative efforts in the United States, which, from the perspective of their current headquarters, indicates that they can only manage these new activities through arm's length control. Given the current mismatch in innovative competencies between Europe and the United States and the need to bridge these differences, innovation management and also general management of the restructuring processes that these companies are undergoing are becoming a truly international affair for these companies. It certainly implies that the restructuring of the traditional publishing industry due to the effects of the new economy, with the extended use of information and communications technologies, will have a profound effect on the management of innovation processes in leading European companies.

As our study is clearly of an exploratory nature, we will briefly discuss a number of recommendations for further study. First, more detailed research is needed to further unravel the complexity of investment preferences of a large, international group of publishing companies in the information and communication industries. The depth of these future studies should provide a better understanding 
of how companies reconsider their strategies and change their product portfolios in the context of core activities in the new economy. Perhaps even more important, these future studies can also investigate changes in the information and communication landscape that affect a larger group of industries. Second, the relationship between diversification and investment modes can be linked to the study of investment preferences and the selection of certain international regions. Such studies can provide insight into the concentration of state-of-the-art technological developments in some dominant regions, such as parts of the United States, and analyze the importance of the growth of relevant new businesses that are building important sections of the new economy in, for instance, North America and Europe. Third, our current study compares strategic alternatives used by Dutch publishing companies and the influence of their strategic mix on different investment options. Further research should not only consider the strategies of publishing companies but also look at their organizational structures. The interaction between strategy and structure can provide further insight into the choice for different investment modes and their organizational implications. That line of research can also analyze the ramifications of the new economy for the organizational structures of companies from traditional industries that might face changes in their organizational and management structures. Finally, this contribution focuses on majority acquisitions, minority acquisitions, and joint ventures. The absorption of at least part of the environment of companies by means of acquisitions and joint ventures, however, represents a limited number of alternatives to the acquisition of new technological capabilities. Future studies could consider other alternatives, such as a wide array of alliances and licensing agreements, that would have different implications for the investment options of companies that are operating in changing environments such as those that are the main subject of the current study.

\section{Notes}

1. We are aware that companies can use other mechanisms, such as contracts and licenses, to enter into new activities (Hagedoorn, 1993). However, mergers, acquisitions, and joint ventures are more relevant in the context of investment strategies with (partial) ownership transfer and the actual acquisition of new technological competencies.

2. With respect to the investment mode, three categories were defined. Using the data on consolidations available in the specific company reports, we were able to identify how the companies' investments are related to the activities and businesses from the traditional and new economy. If the company acquired only activities from the so-called new economy, then its investment is characterized as unrelated diversification. If the consolidation was listed as investment in only activities and businesses from the traditional economy, then the investment mode is defined as traditional diversification. In all other cases, the company acquired activities from the traditional economy and the new economy at the same time. This investment mode is categorized as related diversification. (See also Table 2.)

3. The information used in this section is found in annual reports and other publications by Reed Elsevier, VNU, and Wolters Kluwer and some additional sources, such as Dunn and Bradstreet data, Reach, WorldScope, newspapers, and specialized journals that report on business events. 


\section{See note 2 .}

5. The chi-square test is only valid if three conditions are met. First, the data must be independent. No subject can appear in more than one cell of the table. Second, no more than 20 percent of the calculated expected frequencies in the table can be less than five. Third, no cell should have an expected frequency value of less than one. To meet these conditions, we aggregated minority stake, majority stake, and mergers into one variable: acquisition.

6 . To meet the conditions, we have merged some groups together and ended up with three different locations: EU and EFTA, North America, and the rest of the world.

\section{References}

Beamish, P. W., and J. C. Banks. "Equity Joint Ventures and the Theory of the Multinational Enterprise." Journal of International Business Studies, 19 (1987), 1-16.

Beamish, P. W., and A. C. Inkpen. "Keeping International Joint Ventures Stable and Profitable." Long Range Planning, 28 (1995), 26-36.

Bennett, J. "Discovering America Again." Magazine for Magazine Management, 28 (1999), 53-59.

Besanko, D., D. Dranove, and M. Shankley. Economics and Strategy. New York: John Wiley, 1996.

Chakrabarti, A., J. Hauschildt, and C. Sueverkruep. "Does It Pay to Acquire Technological Firms?" R\&D Management, 24 (1994), 47-56.

Datta, D. K. "Organizational Fit and Acquisition Performance: Effects of Post-acquisition Integration." Strategic Management Journal, 12 (1991), 281-97.

de Ridder, J. A. Persconcentratie in Nederland, Begripsvorming, Bepaling en Beschrijving. Amsterdam: VU Uitgeverij, 1984.

Freeman, C., and J. Hagedoorn. "Convergence and Divergence in the Internationalization of Technology." In Technical Change and the World Economy: Convergence and Divergence in Technology Strategies, ed. J. Hagedoorn. Aldershot, UK: Edward Elgar, 1995.

Geringer, J. M. Joint Venture Partner Selection. New York: Quorum Books, 1988.

Geringer, J. M., and L. Hebert. "Control and Performance of International Joint Ventures." Journal of International Business Studies, 20 (1989), 235-54.

Grandstrand, O., E. Bohlin, C. Oskarsson, and N. Sjoberg. "External Technology Acquisition in Large Multi-technology Corporations." R\&D Management, 22 (1992), 111-33.

Hagedoorn, J. "Understanding the Rationale of Strategic Technology Partnering: Interorganizational Modes of Cooperation and Sectoral Differences.” Strategic Management Journal, 14 (1993), 371-85.

- "A Note on International Market Leaders and Networks of Strategic Technology Partnering." Strategic Management Journal, 16 (1995), 241-50.

Harrigan, K. R. Strategies for Joint Ventures. Lexington, MA: Lexington Books, 1985.

Hitt, M. A., R. E. Hoskisson, R. A. Johnson, and D. D. Moesel. "The Market for Corporate Control and Firm Innovation." Academy of Management Journal, 39 (1996), 1084-119.

Hitt, M. A., R. E. Hoskisson, and H. Kim. "International Diversification: Effects on Innovation and Firm Performance in Product-Diversified Firms." Academy of Management Journal, 40, 4 (1997), 767-98.

Hoskisson, R. E., and M. A. Hitt. Downscoping: How to Tame the Diversified Firm. New York: Oxford University Press, 1994.

Klepper, S. "Industry Life Cycles." Industrial and Corporate Change, 6 (1997), 145-81. Kusewitt, Jr., J. B. "An Exploratory Study of Strategic Acquisition Factors Relating to Performance.” Strategic Management Journal, 6 (1985), 151-69. 
Lichtenberg, L. "Influences of Electronic Developments on the Role of Editors and Publishers: Strategic Issues." International Journal on Media Management, 1 (1999), 23-30.

Link, A. N. "Acquisitions as Sources of Technological Innovation." Mergers and Acquisitions, 23 (1988), 36-39.

Maddala, G. S. Limited Dependent and Qualitative Variables in Econometrics. Cambridge: Cambridge University Press, 1983.

Mowery, D. C. International Collaborative Ventures in U.S. Manufacturing. Cambridge: Ballinger, 1988.

Oster, S. M. Modern Competitive Analysis. New York: Oxford University Press, 1994.

Pfeffer, J. "Merger as a Response to Organizational Interdependence." Administrative Science Quarterly, 17 (1972), 382-94.

Porter, M. E. "From Competitive Advantage to Corporate Strategy." Harvard Business Review (May-June 1987), 43-59.

Schmidt, P., and R. P. Strauss. "The Predictions of Occupation Using Multiple Logit Models." International Economic Review, 16 (1975), 471-86.

Singh, H., and C. A. Montgomery. "Corporate Strategies and Economic Performance." Strategic Management Journal, 8 (1987), 377-86.

Sutton, C. J, Economics and Corporate Strategy. Cambridge: Cambridge University Press, 1980.

Theil, H. "A Multinomial Extension of the Linear Logit Model." International Economic Review, 10 (1969), 251-59.

van den Brink, R. E. M. Economische Structuur en Ontwikkeling van de Informatiemedia in Nederland 1938-1985, in het bijzonder die met betrekking tot de Uitgeverij. Leiden: Stenfert Kroesse, 1987.

Vernon, R. "International Investment and International Trade in the Product Life Cycle." Quarterly Journal of Economics, 80 (1966), 190-207.

Williamson. O. E. The Mechanisms of Governance. Oxford: Oxford University Press, 1996. 